\title{
EDITORS' REPORT
}

This "insurance economics" issue of The Geneva Papers on Risk and Insurance is entirely composed with papers submitted to the refereeing process. Three of these papers were submitted in 1986 and one in 1987.

At the end of 1986, three papers were still in process. One of them had been returned for major revision, two were still under review. In March 1988, the status of these papers is as follows:

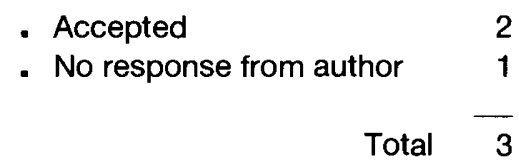

Sixteen new manuscripts were submitted in 1987. Their status is as follows:

- Not suitable 10

- Accepted after minor revision 3

- Accepted after major revision -

- Returned for major revision 3

- Still under review

Total 16

For 1987 the editors gratefully acknowledge the help of the following referees:

- Baruch BERLINER

- George BLAZENKO

- Roger BOWLES

- Eric BRIYS

- Robert CARTER

- Jean-Paul CRESTA

- Jean-Pierre DANTHINE

- Stephen D'ARCY

- Jack DOWIE

- Pascal DUMONTIER

- Louis EECKHOUDT

- Roland EISEN

- Jörg FINSINGER

- Rajna GIBSON-ASNER
- Patrick GOUGEON

- M. HAMMERTON

- Steve HARRINGTON

- Walter KARTEN

- Cheng-few LEE

- Jean LEMAIRE

- Jean-François OUTREVILLE

- Harris SCHLESINGER

- Matthias Graf v.d. SCHULENBURG

- Steven SHAVELL

- Yves SIMON

- Goran SKOGH

- George SZPIRO

- Philippe VAN NAMEN 